\title{
Erratum to: Tick-borne encephalitis in the age of general mobility
}

\author{
J. Süss, O. Kahl, H. Aspöck, K. Hartelt, A. Vaheri, R. Oehme, G. Hasle, H. Dautel, C. Kunz, N. Kupreviciene, \\ S. Randolph, H. P. Zimmermann, B. Atkinson, G. Dobler, K. Kutsar, F. X. Heinz and R. Steffen
}

Received: May 18, 2009/Published online: March 23, 2010

Erratum to: Wien Med Wochenschr

DOI $10.1007 /$ s10354-010-0756-7

Erroneously Prof. Randolph and Prof. Steffen were listed as co-authors of the original publication "Tick-borne encephalitis in the age of general mobility" Süss J, Kahl O, Aspöck H, Hartelt K, Vaheri A, Oehme R, Hasle G, Dautel H, Kunz C, Kupreviciene N, Randolph S, Zimmermann HP, Atkinson B, Dobler G, Kutsar K, Heinz FX, Steffen R, Wien Med Wochenschr, 2010 Feb; 160(3-4): 94-100.

The paper is corrected to “Tick-borne encephalitis in the age of general mobility” Süss J, Kahl O, Aspöck H, Hartelt K, Vaheri A, Oehme R, Hasle G, Dautel H, Kunz C, Kupreviciene N, Zimmermann HP, Atkinson B, Dobler G, Kutsar K, Heinz FX, Wien Med Wochenschr, 2010 Feb; 160(3-4): 94-100.

The version of the original article can be found under DOI: 10.1007/ s10354-010-0756-7

Correspondence: Jochen Süss, M.D., National Reference Laboratory for tick-borne diseases, Friedrich Loeffler Institute, Naumburger Straße 96a, 07743 Jena, Germany.

Fax: ++49 3641 804-228, E-mail: jochen.suess@fli.bund.de 